\title{
Erratum to: Isolation of proline-based cyclic dipeptides from Bacillus sp. N strain associated with rhabditid entomopathogenic nematode and its antimicrobial properties
}

\author{
Nishanth Kumar • C. Mohandas - Bala Nambisan • \\ D. R. Soban Kumar • Ravi S. Lankalapalli
}

Published online: 17 October 2013

(C) Springer Science+Business Media Dordrecht 2013

Erratum to: World J Microbiol Biotechnol

DOI 10.1007/s11274-012-1189-9

Unfortunately, the word rhabditid has been misspelled in article title and under the Discussion head. Corrected word has been published in the erratum title.

The online version of the original article can be found under doi:10.1007/s11274-012-1189-9.

N. Kumar · C. Mohandas · B. Nambisan

Division of Crop Protection/Division of Crop Utilisation,

Central Tuber Crops Research Institute, Thiruvananthapuram,

Kerala, India

D. R. S. Kumar · R. S. Lankalapalli ( $₫)$

Agroprocessing and Natural Products Division, National

Institute for Interdisciplinary Science and Technology (NIIST),

Council of Scientific and Industrial Research (CSIR),

Thiruvananthapuram 695019, Kerala, India

e-mail: ravishankar@niist.res.in 